\title{
Abstract \\ Corrosion Properties of Biodegradable AZ31 and ZK60 Magnesium Alloys: In Situ Study ${ }^{\dagger}$
}

\author{
Evgeniy Merson, Vitaliy Poluyanov (D), Dmitry Merson (1) and Pavel Myagkikh * \\ Institute of Advanced Technologies, Togliatti State University, 445667 Togliatti, Russia; \\ feanorhao@gmail.com (P.M.); vitaliy.poluyanov@gmail.com (V.P.); mersoned@gmail.com (D.M.) \\ * Correspondence: d.merson@tltsu.ru \\ + Presented at the First Corrosion and Materials Degradation Web Conference, 17-19 May 2021; Available online: \\ https://cmdwc2021.sciforum.net/.
}

check for updates

Citation: Merson, E.; Poluyanov, V.; Merson, D.; Myagkikh, P. Corrosion Properties of Biodegradable AZ31 and ZK60 Magnesium Alloys: In Situ Study. Mater. Proc. 2021, 6, 3. https:// doi.org/10.3390/CMDWC2021-09959

Academic Editor: Cuie Wen

Published: 8 May 2021

Publisher's Note: MDPI stays neutral with regard to jurisdictional claims in published maps and institutional affiliations.

Copyright: (C) 2021 by the authors. Licensee MDPI, Basel, Switzerland. This article is an open access article distributed under the terms and conditions of the Creative Commons Attribution (CC BY) license (https:/ / creativecommons.org/licenses/by/ $4.0 /)$.
Abstract: Biodegradable magnesium alloys are promising materials for application in medicine. The corrosion rate and type of corrosion are among the most important properties for this kind of materials. The fine-grained biodegradable alloys AZ31 (hot-rolled) and ZK60 (extruded) were studied in the present work with the use of in situ methods including the hydrogen evolution corrosion rate measurement and real-time surface observation as well as ex situ methods such as the weight loss assessment and the post-mortem examination by confocal laser scanning microscopy. The experimental methods included immersion test in $\mathrm{SBF}(0.9 \% \mathrm{NaCl}$ aqueous solution) during $120 \mathrm{~h}$ with $37^{\circ} \mathrm{C}$ with recirculating corrosion media. The hydrogen evolution was measured with a burette with a constant time interval of 1 hour. The real-time surface observation was carried out with a high-resolution camera. The measurement of $\mathrm{pH}$ level was done twice a day. Corrosion rate curves, 3D morphology of corroded morphology and video recordings showing evolution of corrosion damage have been obtained. As a result, ZK60 was found to be less corrosion-resistant and addicted to pitting corrosion, whereas AZ31 showed pronounced susceptibility to filiform corrosion.

Keywords: magnesium alloys; biodegradable materials; in situ investigation; corrosion rate; corrosion mechanism

Supplementary Materials: The following are available online at https://www.mdpi.com/article/10 .3390/CMDWC2021-09959/s1.

Institutional Review Board Statement: Not applicable.

Informed Consent Statement: Not applicable. 